УДК 82.161.2+82.111]-343.091

https://doi.org/10.31548/philolog2019.01.014

\title{
PANTELEIMON KULISH'S SYMBOLIC IMAGERY IN COMPARISON TO THE CRISTIAN AND MYTHOLOGICAL ARCHETYPAL SYMBOLISM (BASED ON THE STORY "GRANNY FROM THE OTHER WORLD”)
}

\author{
N. K. KRAVCHENKO, Dr. in Philology, Professor, \\ National University of life and environmental sciences of Ukraine,
} E-mail: nkravchenko@outlook.com ORCID: 0000-0001-9839-6629

\begin{abstract}
The paper focuses on the symbolic imagery of the P. Kulish's story "Granny from the other World" in the framework of its relation to the fairy tale / mythological and Christian word pictures. The research aims at identifying the symbolic images of the Kulish's story in their comparison to Christian and mythological concepts while undertaking the images' comparative semiotic and archetypal analysis. To achieve the purpose, we have applied the methodology composing of the methods of archetypal analysis, text and contextual interpretation analysis, elements of the structural-narrative, stylistic and comparative analysis. The major findings refer to the identification of the Kulish's story symbolic imagery in its comparison to the fairy tale and Christian archetypal symbolism. The similarities between the images of the story and mythological world picture encompass the human soul metamorphosis into an animal or a bird based on totemic beliefs and mythological motif of the reincarnation; the images of mediators and loci of transition to another world, the inner "structure" of the other world and a boundary space between the worlds; images of the sacred trees significant for mythological consciousness of the Ukrainians. Some fairy-tale images are metaphorically reinterpreted within the framework of the Christian worldview. Correlative symbolic images differ in their archetypal basis rooted it either Christian or mythological world pictures. Figurative symbolism of Hell in Kulish's story matches Christian symbolic imagery in regards of the "mirror" iconicity, reproducing the "structural" similarity between the nature of sin and its resulting punishment.
\end{abstract}

A description of the symbolic images of the P. Kulish's story contributes to the further study of the archetypally-bound belief system of the Ukrainians.

Keywords: symbolic images, Panteleimon Kulish, Christian, mythological, archetype.

Introduction. Panteleimon Kulish's works represents the symbolic unity in diversity of Christian and mythological images, the latter reflected, in particular, by fairy tales, with which P. Kulish's stories have a lot in common. In view of this, this paper focuses on the identification of the archetypal symbolism of the narrative "Granny from the other World" [5] in the framework of similarity and difference between mythological (pagan, in its roots) and Christian world pictures, the latter embodying the value concepts based on the New and Old Testaments, patristic, church-liturgical, hagiographical, theological, ecclesiological, and mystical sources.

Recent research and publications. Unfortunately, the problem of the Cristian and mythological symbolism of Panteleimon Kulish's works in its comparative facet remains unexplored both in Ukrainian or foreign studies, which determines the scientific relevance of this article. To some extend our paper relies on the theory of cultural archetypes [2; 8; $9 ; 12]$, in view of their correlation with both Cristian and folklore symbols. The studies of symbol considered to be one of the most problematic issues in 
linguosemiotic and interdisciplinary research framework (as indicated by the numerous definitions of this phenomenon $[3 ; 6 ; 7]$ also contributed to the imagery symbolism specified by the story. Of particular importance for this paper are investigations that focus on the folk tales as an ethno-specific phenomenon, which reflects the mythological consciousness of the Ukrainian ethnos, its worldview and naive picture of the world $[1 ; 7 ; 10]$.

The purpose of this article consists in revealing the symbolic images of the Kulish's story in the framework of their Christian and mythological archetypal basis.

Data and methods. The data analyzed in this paper include the symbolic images and motifs identified in P. Kulish's story "Granny from the other World". The collected data are analyzed as follows: the first step consists in identification of the images referred to the "other world", as well as the loci and mediators of transition appropriates for both the fairy tale and Cristian symbolism. In that, we make use of contextualinterpretational and comparative analysis. The second step specifies the story's images that differ according to the criterion of their correspondence either to the mythological or Christian word pictures while revealing the symbolic imagery archetypical basis. The third step consists in identification of the story's images apparently similar both to the fairy tales or Christian symbolic imagery while having different archetypical underpinning in mythological and biblical world pictures. The last two stages of investigation involve the methods of comparative analysis, archetypal analysis, and some elements of the structural-narrative and stylistic analysis.

Results. The symbolic imagery of the Kulish's story explicates a number of symbols common to both the Christian and mythological world pictures. Certain correlations between the imagery of the
Kulish's story, on the one hand, and symbolic structures of the Cristian and mythological beliefs, on the other hand, relate to the understanding of death as a separation of soul from body, ordeals, the image of hell as an inhomogeneous abyss, which levels depend on the degree of sin, the images of sinners' sufferings, the presence of an assistantguide, the boundaries between this and the "other world", the conceptual motive of the inevitable punishment for sins, the image of a bird, into which the soul becomes transformed after separation from the body (Як замахне косою, а душа тільки пурх! так як пташка вилетіла та й полетіла, полетіла по хаті, і сіла в кутку на образі, під самою стелею), etc.

However, this apparent similarity does not exclude certain differences between interpretation of the same images by fairy tales and Cristian semiosphere. Thus, in the Christian tradition the bird symbolizes the human soul. On the other hand, in the mythologies bird is also associated with soul, though implying an additional mythological motif of the reincarnation of the soul into a bird / animal, closely related, according to the totemic beliefs of the archaic person, to the "other" world.

The difference is also evident in regards to mediators and loci of transition to another world. According to the Christian world picture, the soul is accompanied by the Guardian Angel, sometimes - by saints or clergyman (living or dead), and dead relatives. In the story, the function of the guide to the other world is performed by The Old Man (Дивлюсь, аж не сама я йду, а веде мене якийсь дід, а куди він мене веде, боюсь спитаmuся), associated with the fairy-tale character of Did-Vsevid. The locus of transition is the Dubynyha's house as a that prevents the soul from getting free ( $А$ гріхи стали на порозі та й не пускають душі з хати), and the 
abyss (which is metonymically linked to the notions of hell as the bottomless pit $(A$ проваллє таке глибоченне, що й дна не видно) and metaphorically or iconically - with sin as the Fall).

Other discrepancy concerns the "nature" of the other world. If in fairy tales the destructive force of this world manifests itself on its border with the world of the living (it is difficult to get to it, it is necessary to cross the forest, a dangerous river, etc.), while the other world itself is the kingdom of peace where everything happens as if in a dream (for example, a fairy tale about the gold, silver and copper kingdoms or the underwater kingdom). In contrast to the fairy tale «netherworld» in the Kulish's story recreates the Christian picture of the world with the existence of Paradise and Hell, in which "weeping and gnashing of teeth" («Нехай вони знають, що то за муки пекельнії, нехай памятають на праведний суд Божий»).

The fairy-tale events, described by P. Kulish, match religious beliefs in regard to the images of Hell, i.e. the image of a boiling pitch, thirst, and fire. At the same time, the sinner in the Kulish's narrative burns between two oaks, (аж між двома дубами горить у поломі чоловік і кричить: Ой, пробі! Укрийте мене, бо замерзну!), which ilvolves some associations with mythological symbolism: the oak in the ethnoconsciousness of the Ukrainians is a metonymic manifestation of the Tree of Life (World Tree) as a symbol of life and immortality [7]. In the symbolic context of the Kulesh's story the symbol of immortality becomes a sign of eternal torment.

Similar with Cristian imagery is the story's motive of suffering from thirst (associated with the parable of the rich man and Lazarus). Being represented by different images in the narrative and Cristian semiotic sphere, this motif is based on the same value basis and contains a common narrative component: suffering in the immediate vicinity of the water source. Thus, in the story of P. Kulish, the sinner лежить коло криниці; тече йому рівчак через рот, а він кричить, щоб йому дали напитися. In the life of the martyress Perpetua (III century), for example, her brother's postmortal fate was revealed to her through the following image: the boy was lying near a water-filled reservoir, which was located so high that he could not reach it from the intolerably hot place where he was placed.

It should be noted that the figurative symbolism of Hell in P. Kulish's story as well as in the Christian texts is marked by a certain "mirror" iconicity, reproducing the "structural" similarity between the nature of sin and its resulting punishment: the one who did not give a drink to a thirsty, suffers from thirst; not having warmed the wanderer suffers from the cold, while burning in the fire: "Отсе», каже, «той чоловік, що просився до його зімою в хату подорожній, а на дворі була метелиця і хуртовина, а він не пустив, так той і змерз під тином. Отсе ж тепер він горить у поломі, а йому ще здається, що холодно, i терпить він таку муку, як той подорожній терпів од морозу».

Corresponding to the metamorphosis, common to a fairy tale, but different from the canonical religious beliefs is the story's karmic motif of converting the souls of sinners into animals, which correlates with the ancient Old-European idea of karma: «худії воли, то-то багаті люде, що жили самі в розкоші, а бідним не помагали"; «по роги в спашу, та худі як дошка»; «а ситії воли, то-то бідні люде, що од свого рота віднімали та старцям із посліднього давали»). Blood brothers who in their lifetime «погризлись та й побились», turned after their death into two dogs («а вони все вищать та гризуться»). From viewpoint of linguistics, the last image appears as a 
metaphor, which in the semiotic space of the "other world" demetaphorizes, losing its abstract symbolic signs (the dog as a symbol of aggression, anger), or, more precisely, transmit such features into the plane of an off-world "ontological" reality, interpreting the metaphorical projection "man as an evil dog" in the denotative meaning "dog as an evil man".

In the framework of the mythological beliefs of ancient Ukrainians, the image of a dog-man may be associated with the idea of a dog-headed person (песиголовець), a mythical woolly creature with a dog's head, which was considered a symbol of cruelty [7]. In the broader context of world mythology, the motives of the postmortal transformation of humans into animals are based, in our view, on the idea of the impossibility to overcome the autochthonous origin of humans, which together with its dichotomous correlate (the attempt to overcome the autochthony) form one of the basic "mythemes", structuring the myths of different cultures - from the Oedipus myth to the mythology of the Indians - Pueblo (in particular, such mythem was identified by Claude LéviStrauss [4].

Other images that can be interpreted from the viewpoint of fairytale images, but do not contradict Christian symbols, include the image of the Mother of God who is spinning surrounded by the children giving her golden balls: "Мати Божа панчішку плете, а вони перед нею золотії клубочки держять» In fairy tales, spinning usually denotes the process of ordering and harmonization. In the P. Kulish's story the Mother of God also spins, symbolizing supreme harmony, dispensation of grace, Life and salvation. In fairy tales, the ball usually functions as magic assistants to help the hero get to the "other world". In ancient Greek mythology, Ariadne, King Minos's daughter, helps Theseus to find his way back out of the labyrinth, giving him a ball of red thread.

Therefore, the symbolic meaning of the tangle (golden ball) is associated with help and salvation - what is first of all expected of the Mother of God by the people who turn to her in their prayers. At the same time, the tangle / ball is associated with the circle - a symbol of infinity, eternity, perfection and the sun (golden circle) [7]. The fact that the balls in the Kulish's story are gold is no coincidence, since in Christianity the gold itself is a symbol of paradise light, the Divine Glory of Christ (gold was one of the three gifts the Magi brought to the newborn Savior).

Conclusions and discussion. The major findings refer to the archetypal capacity of the Kulish's story symbolic imagery in its comparison to the fairy tale and Christian symbolism. The allomorphic images and motifs include: the human soul metamorphosis into an animal or a bird according to mythologems, based on totemic beliefs and mythological motif of the reincarnation; the images of mediators and loci of transition to the other world, its inner "structure" and a boundary space between the worlds; images of the sacred trees significant for mythological consciousness of the Ukrainians. Some fairy-tale images are metaphorically reinterpreted within the framework of the Christian worldview, i.e. the image of the spinning Mother of God surrounded by the children giving her golden balls, etc. Some symbolic images that seem common or correlative, however, differ in their archetypal underpinning rooted it either Christian or mythological world pictures. Figurative symbolism of Hell in Kulish's story matches Christian symbolic imagery in regards of the "mirror" iconicity, reproducing the "structural" similarity between the nature of $\sin$ and its resulting punishment. 
A description of the symbolic images of the P. Kulish's story will contribute to the further study of the belief system and behavior codes of the Ukrainian ethnos viewed through the imagery archetypal basis, identified by the comparison of the $P$. Kulish's imagery with the Christian or mythological symbols.

\section{Список використаних джерел}

1. Балушок В. Г. Обряди ініціації українців та давніх слов'ян: монографрія. Львів : Просвіта, 1998. 216 c.

2. Бєлєхова Л. І. Архетип, архетипний смисл, архетипний образ у лінгвокогнітивному висвітленні. Науковий вісник ДДПУ імені І. Франка. Серія «Філологічні науки». Мовознавство. 2015. № 3. С. 6-16.

3. Керлот Х. Э. Словарь символов: [Мифология. Магия. Психоанализ: Перевод]. Москва : REFL-book, 1994. $601 \mathrm{c}$.

4. Кравченко Н. К. Дискурс и дискурс-анализ: краткая энциклопедия. Киев : Интерсервис, 2017. 286 с.

5. Куліш П. Бабуся з того світу. Оповідання про померши души. С. 24-33. http://elib.nlu.org.ua/view.html?id=9968

6. Лотман Ю. М. Семиосфрера: Культура и взрыв. Внутри мыслящих миров: Статьи. Исследования. Заметки. Санкт-Петербург : ИскусствоСПБ, 2004. 703 с.

7.Словник символів культури України. https:/library.udpu.edu.ua/library_files/397017.pdf

8. Франц М.-Л. фрон. Архетипические паттерны в волшебных сказках: перевод с англ. В.Мершавки. Москва : "Класс", 2007. 256 с.

9. Юнг К.-Г. Феноменология Духа в сказке. Структура психики и архетипы. Москва : Академический Проект, 2007. C.138-188.

10. Ятченко В.Ф. Метафрізичні виміри української дохристиянської міфології: автореф. дис... д-ра фрілософр. наук : 09.00.04. Київ, 2002. $39 \mathrm{c}$.

11. Fromm, Erich. The Forgotten Language: An Introduction to the Understanding of Dreams, Fairy Tales and Myths. New York: Grove. Fairy-Tale Symbolism: An Overview. Oxford Research Encyclopedias, 1957. URL: http://literature. oxfordre.com/view

\section{References}

1. Balushok V. H. (1988). Obriady initsiatsii ukraintsiv ta davnikh slov'ian. L'viv: Prosvita. 216.

2. Belehova L.I. Arhetyp, arhetypnyj smysl, arhetypnyj obraz u lingvokognityvnomu vysvitlenni. Naukovyj Visnyk DDPU imeni I. Franka. Serija "Filologichni nauky". Movoznavstvo. 2015. № 3. C. 6-16.

3. Kerlot Kh. E. (1994). Slovar' symvolov. Moscow: REFL-book. 601.

4. Kravchenko N. K. (2017). Dyskurs y dyskurs-analyz: kratkaia entsyklopedyia. Kyev: Ynterservys. 286.

5. Kulish P. Babusija $z$ toho svitu. Opovidannija pro pomerli dushi. 24-33. http://elib.nlu.org.ua/view.html?id=9968

6. Lotman, Yu. M. (2004). Semyosfera: Kul'tura y vzryv. Vnutry mysliaschykh myrov. Stat'y.Yssledovanyia. Zametky. Sankt-Peterburh: Yskusstvo-SPB. 703.

7.Slovnyk symvoliv kultury Ukrajiny. https://library.udpu.edu.ua/library_files/39 7017.pdf

8. Frants, M.-L. fon. (2007). Arkhetypycheskye patterny v volshebnykh skazkakh. Moscow: Klass. 256.

9. Jung K-G. (2007). Fenomenologija duha $v$ skazke. Structura psyhyki I arhetipy. Moscow: Akademichnyj proekt. 138-188.

10. Jatchenko V.F. (2002). Metafizychni vymiry ukrajins'koji dohrystyjans'koji mifologiji: avtoref. Dys. ... d-ra filosof. nauk. 
11. Fromm, Erich. The Forgotten Language: An Introduction to the Understanding of Dreams, Fairy Tales and Myths. New York: Grove. Fairy-Tale
Symbolism: An Overview. Oxford Research Encyclopedias, 1957. URL: http://literature. oxfordre.com/view

\section{ВОЛІЧНА ОБРАЗНІСТЬ ТЕКСТІВ ПАНТЕЛЕЙМОНА КУЛІША У ПОРІВНЯННІ 3 ХРИСТИЯНСЬКОЮ І МІФОЛОГІЧНОЮ АРХЕТИПНОЮ СИМВОЛІКОЮ (НА МАТЕРІАЛІ ОПОВІДАННЯ «БАБУСЯ 3 ТОГО СВІТУ»)

\author{
Н. К. Кравченко
}

Анотація. У статті висвітлюється символічна образність твору П. Куліша «Бабуся з того світу» у ї співвіднесенні з казковою / міфрологічною та християнською картинами світу. Дослідження спрямоване на виявлення символічних образів наративу в аспекті їх порівняння з християнськими та міфрологічними концептами із залученням семіотичного та архетипного аналізу образів. Для досягнення зазначеної мети застосовано методологію, що включає методи архетипного аналізу, інтерпретації тексту, контекстуального аналізу, елементи структурно-наративного, стилістичного та порівняльного аналізу.

Основні висновки стосуються ідентифрікації символічних образів оповідання крізь призму символіки казкового наративу та християнської архетипної символіки. Подібність між образами оповідання і міфологічною картиною світу визначається: архетипом трансформації людської душі у тварину чи птаха, що базується на тотемних віруваннях та міфоологічному мотиві перевтілення; образами посередників та локусів переходу до іншого світу, його внутрішньою "структурою" та специфрікою граничного простору між світами; зображенням сакральних дерев, важливих для міфрологічної свідомості українців. Деякі казкові образи метафорично переосмислені в оповіданні в контексті християнського світогляду. Спільні або співвідносні символічні образи відрізняються, натомість, своєю архетипною основою з огляду на відмінність християнської і міфологічної картин світу. Образна символіка Пекла в оповіданні Куліша відповідає християнській символічній образності з огляду на "дзеркальну» іконічність, відтворюючи «структурну» схожість між природою гріха і його наслідком через покарання. Опис символічної образності оповідання П. Куліша сприяє подальшому вивченню архетипного компонента системи вірувань українців.

Ключові слова: символічні образи, Пантелеймон Куліш, християнський, міфологічний, архетип. 